\title{
Analisis Pendapatan Usahatani Jagung di Desa Bannae Kecamatan Insana Barat Kabupaten Timor Tengah Utara
}

\author{
Matilde Hoar Nahak ${ }^{\mathrm{a}}$, dan Simon Juan Kune ${ }^{\mathrm{b}}$ \\ ${ }^{a}$ Fakultas Pertanian, Universitas Timor, Kefamenanu, TTU - NTT, Indonesia. \\ ${ }^{b}$ Fakultas Pertanian, Universitas Timor, Kefamenanu, TTU - NTT, Indonesia.
}

\section{Article Info}

Article history:

Received 14 Juni 2017

Received in revised form 21 Juli 2017

Accepted 6 Oktober 2017

\section{Keywords:}

Pendapatan

Usahatani

Jagung

Banae

Insana Barat

\begin{abstract}
Abstrak
Desa Bannae merupakan salah satu desa yang berada di wilayah kecamatan Insana Barat dan memiliki produktivitas jagung yang tinggi karena masyarakat pada umumnya berprofesi sebagai petani dan menggantungkan hidup mereka pada hasil pertanian. Tujuan penelitian ini adalah untuk mengetahui 1) besarnya pendapatan yang diperoleh petani; dan 2) keuntungan relatif yang diperoleh para petani jagung di desa Bannae kecamatan Insana Barat, kabupaten TTU. Penelitian dilaksanakan di Desa Bannae, kecamatan Insana Barat, kabupaten TTU pada bulan Februari hingga Juni 2017. Populasi berjumlah 413 KK dengan sampel 40 responden. Untuk mengetahui pendapatan usahatani jagung dilakukan analisis pendapatan sedangkan untuk mengetahui keuntungan relatif dilakukan analisis R/C Rasio. Hasil penelitian menunjukkan biaya yang dikeluarkan selama berusahatani jagung selama satu musim tanam ada dua jenis biaya yaitu biaya variabel dan biaya tetap dengan total biaya sebesar Rp17.236.516,00 dengan rata-rata biaya sebesar Rp430.913,00 sedangkan total penerimaan yang diperoleh petani jagung Rp63.190.000,00 dengan rata-rata penerimaan sebesar Rp1.579.750,00 sehingga total pendapatan petani jagung sebesar Rp45.953.483,00 dengan rata-rata pendapatan sebesar Rp1.148.837,00. Keuntungan relatif yang diperoleh petani rata-rata 3,61 dan dapat dikatakan bahwa kegiatan usahatani jagung menguntungkan secara ekonomis dan setiap pengeluaran satu rupiah dapat memberikan rata-rata keuntungan sebesar 3,61. @2017 dipublikasikan oleh Agrimor.
\end{abstract}

\section{Pendahuluan}

Jagung (Zea mays L.) merupakan salah satu komoditas tanaman pangan musiman yang sudah diusahakan oleh masyarakat petani secara turun temurun. Komoditas ini mempunyai fungsi multiguna baik untuk dikonsumsi sebagai sayuran dan juga sebagai substitusi dari beras, maupun digunakan sebagai bahan baku utama industri pakan ternak serta industri pangan olahan. Selain memiliki fungsi multiguna komoditas jagung juga mempunyai kandungan gizi yang baik bagi kesehatan (Rukmana, 1997).

Kabupaten Timor Tengah Utara (TTU) adalah salah satu daerah penghasil jagung dan Insana Barat merupakan salah satu kecamatan yang memberikan kontribusi terhadap produksi jagung di kabupaten TTU. Tahun 2013 kecamatan Insana Barat menghasilkan jagung 751 ton atau 1,2\% dari total produksi jagung kabupaten TTU (63.677 ton) dengan luas panen 296 ha dan produktivitas 2,54 t/ha (BPS Kab. TTU, 2014). Tahun 2014 kecamatan Insana Barat menghasilkan jagung 1.039 ton atau 1,4\% dari total produksi jagung kabupaten TTU (73.114 ton) dengan luas panen 380 ha dan produktivitas 2,73 t/ha (BPS Kab. TTU, 2015). Tahun 2015 kecamatan Insana Barat menghasilkan jagung 2.164 ton atau $3,8 \%$ dari total produksi jagung kabupaten TTU (56.655 ton) dengan luas panen 1.035 ha dan produktivitas 2,09 t/ha (BPS Kab. TTU, 2017). Produktivitas jagung di kecamatan Insana Barat lebih tinggi dari beberapa hasil penelitian terdahulu di beberapa wilayah kabupaten TTU yakni 1 t/ha (Wonkay \& Taolin, 2016), dan 1,4 t/ha (Leki et al., 2016) tetapi masih lebih rendah dari 3,54 t/ha yang dihasilkan dari penelitian (Bhato, 2016). Selain sebagai bahan makanan pokok, jagung di kabupaten TTU juga telah dijadikan sebagai bahan baku industri kecil atau industri rumahan misalnya dimanfaatkan sebagai bahan baku agroindustri tortila atau kerupuk jagung (Falo \& Fallo, 2016) atau digunakan untuk membuat biskuit jagung (Kolo \& Hutapea, 2016).

Desa Bannae merupakan salah satu desa yang berada di wilayah kecamatan Insana Barat dan memiliki produktivitas jagung yang tinggi karena masyarakat pada umumnya berprofesi sebagai petani dan menggantungkan hidup mereka pada hasil pertanian. Pada survei awal diperoleh data dari pendamping lapangan desa Bannae bahwa lahan usahatani jagung tahun 2013 seluas 143 ha dengan produksi sebanyak 256,25 ton, pada tahun 2014 luas lahan 196 ha dengan produksi 392 ton dan tahun 2015 luas lahan 200 ha dengan produksi 460 ton Petani desa Bannae biasanya menjual jagung kering yang sudah dipipil di pasar baru Kefamenanu dan toko sembako lainnya. Pendapatan yang diterima selama ini dari usahatani jagung selain digunakan untuk memenuhi kebutuhan hidup masyarakat, juga digunakan untuk kebutuhan anak sekolah dan mengembangkan usahataninya, meskipun demikian belum dapat dipastikan seberapa besar pendapatan petani setiap musimnya yang bersumber dari usahatani jagung, untuk itu perlu dilakukan kajian dengan topik "Analisis Pendapatan Usahatani Jagung di Desa Bannae Kecamatan Insana Barat Kabupaten Timor Tengah Utara". Tujuan penelitian ini adalah untuk mengetahui 1) besarnya pendapatan yang diperoleh petani; dan 2) keuntungan relatif yang diperoleh para petani jagung di desa Bannae kecamatan Insana Barat, kabupaten TTU.

\section{Metode}

Penelitian dilaksanakan di Desa Bannae, kecamatan Insana Barat, kabupaten TTU pada bulan Februari hingga Juni 2017. Populasi dalam penelitian adalah semua petani jagung di desa Bannae dengan jumlah 413 KK. Pengambilan sampel dilakukan dengan menggunakan metode perposeve Sampling pada petan yang sudah lama berusahatani jagung ( $>10$ tahun) dan petani yang memproduksi jagung dalam jumlah banyak dengan demikian sampel dalam penelitian ini berjumlah 40 responden.

Data yang digunakan dalam penelitian ini adalah data primer yang diperoleh dengan teknik wawancara langsung dengan responden atau petani di lokas penelitian berdasarkan daftar pertanyaan yang disiapkan oleh peneliti sedangkan data sekunder diperoleh dari instansi atau lembaga terkait.
Untuk mengetahui pendapatan usahatani jagung maka dilakukan analisis pendapatan sedangkan untuk mengetahui keuntungan relatif maka dilakukan analisis R/C Rasio sesuai petunjuk (Soekartawi, 1995).

\section{Hasil dan Pembahasan}

\subsection{Biaya Usahatani Jagung}

Biaya usahatani jagung dalam penelitian ini adalah biaya produksi dan jenis biaya yang dikeluarkan adalah biaya variabel atau biaya tidak tetap dan biaya tetap yakni biaya penyusutan alat yang digunakan dalam proses produksi usahatani jagung. Berdasarkan hasil penelitian total biaya usahatani jagung di desa Bannae pada 40 responden sebesar Rp17.236.516,00 dengan rata-rata biaya sebesar Rp430.913.00

a. Biaya Variabel

Berdasarkan hasil penelitian pada usahatani jagung di desa Bannae diperoleh rata-rata biaya variabel dari 40 responden sebesar Rp371.850,00 dengan total biaya variabel sebesar Rp14.874.000,000 seperti pada Tabel 1.

Tabel 1. Rincian Biaya Variabel Usahatani Jagung

\begin{tabular}{clcr}
\hline No & Jenis Biaya Variabel & Rata-rata Biaya $(\mathrm{Rp})$ & Total Biaya $(\mathrm{Rp})$ \\
\hline 1 & Pupuk Urea $(\mathrm{kg})$ & 59.850 & 2.394 .000 \\
2 & Pupuk KCL $(\mathrm{kg})$ & 45.500 & 1.820 .000 \\
3 & Pupuk TSP $(\mathrm{kg})$ & 14.250 & 570.000 \\
4 & Konsumsi & 222.250 & 8.890 .000 \\
5 & Transportasi & 30.000 & 1.200 .000 \\
\hline
\end{tabular}

Penelitian ini tidak menghitung upah tenaga kerja sebab tenaga kerja yang digunakan merupakan tenaga kerja gotong royong artinya bahwa petan bersepakat untuk bekerja bergotong royong oleh karena itu yang dihitung adalah biaya konsumsi dengan sistem gotong royong.

\section{b. Biaya Tetap}

Penyusutan Peralatan yang dihitung dalam penelitian ini meliputi parang, linggis, ember, tajak. Menurut Baridwan, (2008), biaya penyusutan peralatan in dihitung menggunakan metode garis lurus (Straight Line method) dengan rumus Penyusutan $=$ (harga beli - nilai sisa $) /$ umur ekonomis. Berdasarkan hasil penelitian diperoleh total biaya penyusutan alat dari 40 responden sebesar Rp2.362.517,00 dengan rata-rata Rp59.063,00 seperti pada Tabel 2.

Tabel 2. Rincian Biaya Tetap (Penyusutan Alat) Usahatani Jagung

\begin{tabular}{clcc}
\hline No & Jenis Alat & Rata-rata Biaya $(\mathrm{Rp})$ & Biaya Penyusutan $(\mathrm{Rp})$ \\
\hline 1 & Parang & 9.737 & 389.476 \\
2 & Linggis & 23.513 & 940.500 \\
3 & Ember & 11.845 & 473.800 \\
4 & Tajak & 13.969 & 558.750 \\
\hline
\end{tabular}

\subsection{Penerimaan Usahatani Jagung}

Penerimaan dalam penelitian ini mengikuti prinsip Soekartawi, (1995) dan satuan yang digunakan untuk usahatani jagung adalah kilogram $(\mathrm{kg})$ ditingkat petani dan harga yang ditetapkan sebesar Rp5.000,00 per kilogramnya. Produksi usahatani jagung dalam satu musim tanam dari 40 responden diperoleh sebesar $12.638 \mathrm{~kg}$ dengan rata-rata $316 \mathrm{~kg}$, dengan demikian penerimaan 40 responden petani usahatani jagung sebesar Rp63.190.000,00 dengan rata-rata penerimaan responden sebesar Rp1.579.750,00.

\subsection{Pendapatan Usahatani Jagung}

Hasil perhitungan 40 responden petani jagung diperoleh total biaya sebesar Rp17.236.516,00 dengan rata-rata total biaya Rp430.913,00 dan total penerimaan sebesar Rp63.190.000,00 dan rata-rata penerimaan sebesar 
Rp1.579.750,00. Hasil perhitungan tersebut kemudian diinterpretasikan dalam rumus pendapatan sehingga diperoleh total pendapatan dari 40 responden petani jagung sebesar Rp45.953.483,00 dengan rata-rata pendapatan sebesar Rp1.148.837,00. Pendapatan ini jauh lebih rendah dibandingkan dengan pendapatan petani di desa Bitefa kecamatan Miomaffo Timur yakni sebesar Rp13.022.217,39 (Kune, 2017).

\subsection{Keuntungan Relatif (R/C Ratio) Usahatani Jagung}

Penelitian ini yang dibandingkan adalah total penerimaan dengan total biaya dari 40 responden petani jagung. Berdasarkan hasil perhitungan diperoleh total $\mathrm{R} / \mathrm{C}$ Ratio dari 40 responden petani jagung sebesar 144,53 dengan rata-rata R/C ratio sebesar 3,61.

\section{Simpulan}

Biaya yang dikeluarkan selama berusahatani jagung selama satu musim tanam ada dua jenis biaya yaitu biaya variabel dan biaya tetap dengan total biaya sebesar Rp17.236.516,00 dengan rata-rata biaya sebesar Rp430.913,00 sedangkan total penerimaan yang diperoleh petani jagung Rp63.190.000,00 dengan rata-rata penerimaan sebesar Rp1.579.750,00 sehingga total pendapatan petani jagung sebesar Rp45.953.483,00 dengan rata-rata pendapatan sebesar Rp1.148.837,00. Keuntungan relatif yang diperoleh petani rata-rata 3,61 dan dapat dikatakan bahwa kegiatan usahatani jagung menguntungkan secara ekonomis dan setiap pengeluaran satu rupiah dapat memberikan rata-rata keuntungan sebesar 3,61.

\section{Pustaka}

Baridwan, Z. 2008. Sistem Akuntansi Penyusunan Prosedur dan Metode. 5 ed. Yogyakarta: BPPE.

Bhato, M.A. 2016. Respon Pertumbuhan dan Hasil Jagung (Zea mays L.) Varietas Pioner terhadap Berbagai Takaran Pupuk Kandang Babi dan Jarak Tanam. Savana Cendana, 1(02): 85-89.

BPS Kab. TTU 2014. Timor Tengah Utara dalam Angka 2014. Kefamenanu: Badan Pusat Statistik Kabupaten TTU.

BPS Kab. TTU 2015. Timor Tengah Utara dalam Angka 2015. Kefamenanu: Badan Pusat Statistik Kabupaten TTU.

BPS Kab. TTU 2017. Kabupaten Timor Tengah Utara dalam Angka 2017. Kefamenanu: Badan Pusat Statistik Kabupaten TTU.

Falo, M. \& Fallo, Y.M. 2016. Kajian Pendapatan Agroindustri Tortila di Kecamatan Insana Barat Kabupaten Timor Tengah Utara. AGRIMOR, 1(02): 19-20.

Kolo, D. \& Hutapea, A.N. 2016. Strategi Pengembangan Usaha Biskuit Jagung di Kelompok Wanita Tani Lestari Desa Subun Tua'lele, Kecamatan Insana Barat, Kabupaten Timor Tengah Utara. AGRIMOR, 1(03): 42-45.

Kune, S.J. 2017. Analisis Pendapatan dan Keuntungan Relatif Usahatani Jagung di Desa Bitefa Kecamatan Miomaffo Timur Kabupaten TTU. AGRIMOR, 2(02): 23-24.

Leki, W., Lelang, M.A. \& Taolin, R.I. 2016. Pengaruh Takaran Pupuk Kandang Sapi Terhadap Pertumbuhan dan Hasil Jagung (Zea mays, L.) yang Ditumpangsarikan dengan Kedelai (Glysine max,(L.) Merril). Savana Cendana, 1(01): 17-23.

Rukmana, R. 1997. Usaha Tani Jagung. Yogyakarta: Kanisius.

Soekartawi 1995. Analisis Usaha Tani. Jakarta: Universitas Indonesia Press.

Wonkay, R.E. \& Taolin, R.I.C.O. 2016. Pengaruh Model Penyimpanan Benih dan Jenis Pupuk Kandang terhadap Pertumbuhan dan Hasil Jagung (Zea mays L.). Savana Cendana, 1(04): 128-132. 